\title{
Lenguaje denso y apertura: \\ otra vindicación de la poesía como órgano del conocimiento
}

\author{
Dense language and opening: \\ another vindication of poetry as an organ of knowledge
}

Juan Ignacio Blanco Ilari*

\begin{abstract}
Resumen: Este trabajo se enmarca dentro de las innumerables vindicaciones de la poesía. Comienza con el desarrollo de las cuatro características del "lenguaje poético" en tanto "lenguaje denso". La figuratividad o metaforicidad, su alusividad, la identidad forma-contenido y el realismo poético. En el segundo apartado se analizan estas características a la luz de las categorías de "significatividad" y de "interpretante". La ontología heideggeriana y la semiótica peirceana enriquecen el concepto de lenguaje denso y aclaran su poder epistémico. Finalmente, analizo algunos aspectos que Nietzsche, en su período retórico (1869-1874), elabora sobre el lenguaje, y que prefiguran y amplían la noción de lenguaje denso. Me centro allí en la idea que todo lenguaje es, en su origen, retórica, y en el modo en que el proceso comunicativo atenta contra dicho origen. Me interesan, en particular, las nociones de "fijación", "olvido" y "restauración".
\end{abstract}

Palabras clave: lenguaje denso, poético, significatividad, retórica.

Abstract: This work is framed within the innumerable vindications of poetry. It begins with the development of the four characteristics of "poetic language" as "dense language". Figurativity or metaphoricity, its allusiveness, form-content identity, and poetic realism. In the second section, these characteristics are analyzed in the light of

* Doctor, Licenciado y Profesor de Filosofía (Universidad Nacional de La Plata, Argentina), docente de la Pontificia Universidad Católica Argentina (Filosofía Contemporánea) y de la Universidad Nacional de General Sarmiento, Argentina (Filosofía Moderna y Ética). Investigador Adjunto del Consejo Nacional de Investigaciones Científicas y Técnicas (CONICET). Tema de investigación: Retórica y Filosofía. Dirección electrónica: juan_blanco2001ar@hotmail.com 
the categories of "significance" and "interpretant". The heideggerian ontology and the peircean semiotics enrich the concept of dense language and clarify its epistemic power. Finally, I analyze some aspects that Nietzsche, is his rhetorical period (1869-1874), elaborates on language, aspects that prefigure and expand the notion of dense language. I focus there on the idea that all language is, in its origin, rhetoric, and in the way in which the communicative process attacks that origin. I am particularly interested in the notions of "fixation", "forgetting" and "restoration".

Key words: Dense language, poetic, significance, rhetoric.

\section{a) Introducción}

Veinticuatro siglos de constante desagravio de la poesía son una prueba contundente, aunque indirecta, del impacto que La República tiene en nuestra cultura. Desde luego, la cultura no es algo monolítico y homogéneo, y un libro es el conjunto de sus recepciones. Sin embargo, desde que Platón expulsó a los poetas (y oradores) de su estado ideal (acusándolos de falsificadores, embusteros, timadores), se ha ido consolidando una perspectiva sobre la poesía ( $y$ el arte en general) que, entiendo, no le hace justicia. Obviamente, me encuentro muy bien acompañado en esta vindicación. Las primeras reacciones ante esta mirada reductiva y fantasmal del quehacer de los poetas se hicieron sentir por algunos contemporáneos del mismo Platón (pensemos en Isócrates, en el movimiento sofista, en los grandes trágicos), y luego se replicaron en ilustres pensadores. Pero el temple del platonismo (en este tema) se muestra en el nivel de permeabilidad con que ha sabido capturar buena parte de nuestra mirada hacia el arte. Si bien ha mermado la crudeza de la acusación, el arte sigue siendo minusvalorado como vehículo del saber, sigue estando preso del proceso de desontologización que se soldó durante la Modernidad. El arte, dicen, expresa el sentir del artista, no cómo son las cosas. Para esto tenemos la ciencia.

Limpiando las razones más hiperbólicas que aparecen en el argumento platónico, podríamos afirmar que ver en el arte un producto de la imaginación, y en la imaginación una facultad que nos evade de la realidad por medio de la creación de mundos ficticios, encantados, es algo de sentido común. Los más atrevidos han llegado a declarar que el arte forma parte de la infancia de la humanidad, y que, de un tiempo a esta parte, asistimos a sus exequias. Sostienen 
que los procesos de racionalización que cruzan toda la cultura occidental, desde Platón en adelante, provocan un inevitable y progresivo "desencantamiento" del mundo (Weber), que se traduce, entre otras cosas, en la subjetivización de la experiencia estética. Esa es la victoria del paradigma que llamamos "platónico" (y que excede en mucho a Platón).

Pero hay algo en el arte, y también en el sentido común que se nutre del arte, que se ha resistido a este lapidario juicio. Algo tiene la poesía que genera un atractivo que no se deja explicar sólo con la categoría de "evasión", de "fuga de la realidad", ni siquiera con la de "placer" o "sentimiento". Para muchos filósofos, y muchísimos profanos, el arte en general, y la poesía en particular, gozan de un poder único, inigualable, de revelar, de mostrar "lo que las cosas son". Tienen, lo que llamaríamos con algo de solemnidad, "alcance ontológico".

Indagar un poco ese poder (que es también una resistencia) es el objetivo de este trabajo. Su proceder puede resumirse así: quiere desarrollar el concepto de "lenguaje denso" (o sencillamente "densidad") como categoría esencial del lenguaje poético, y mostrarlo como el catalizador de aquel poder de revelación.

La estructura general del trabajo está compuesta de tres instancias. En primer lugar, desarrollaré lo que considero las cuatro características centrales del "lenguaje denso": "figuratividad", "alusividad", "identidad formacontenido" y "ser respuesta a una exigencia de la cosa". Ante la dificultad de dar una definición que deje tranquilos a todos, propongo recorrer algunas de las líneas que caracterizan (y permiten distinguir) al lenguaje denso. Es probable que estas características no sean exhaustivas, y no se apliquen sólo a la poesía (o al arte en general), pero eso es motivo de otro trabajo.

El segundo movimiento (apartado (C)) intenta apuntalar la noción de lenguaje denso con el concepto de "significatividad" (Bedeutsamkeit) tal como lo trabaja el joven Heidegger, y con la noción de "interpretante" (y sus correlatos: "campo semántico" y "connotación") cara a la semiótica posterior a Peirce. Ambas categorías enriquecen e iluminan la noción de "lenguaje denso", al tiempo que parecieran desprenderse de ella.

Finalmente, en el tercer movimiento, me pertrecho de algunas reflexiones de Nietzsche, de lo que podríamos denominar su "período retórico" (1869 a 1874). Me interesa en particular cómo opera en esas 
reflexiones la noción de "fijación", de "liberación", de "olvido" y de "restauración", y cómo se aplican al lenguaje denso. Apelar a la filosofía de Nietzsche (quizá uno de los más grandes rehabilitadores de la noción del arte como vehículo del conocimiento) me dará, así lo espero, una apoyatura de cierre a lo dicho en los otros dos apartados.

Por supuesto, el tema es de una amplitud intimidante. No quiero, ni puedo, agotarlo en estos pocos renglones.

Una última e innecesaria aclaración. El artículo, como se habrá advertido, es sobre poesía. Sin embargo, no se citarán versos. Sólo haré referencia a un poeta (mas no a su poesía, sino a sus reflexiones sobre la poesía) del cual todavía no he podido liberarme. Es posible que todo este trabajo sea la respuesta a una provocación que advierto en sus líneas.

\section{b) El concepto de "densidad"}

Una buena forma de ingresar en la peculiaridad del significado poético es contrastándolo con otro modelo de significación que se coloca en las antípodas: el científico. La contraposición poesía/ciencia es tan antigua como la coexistencia de ambas disciplinas. El contraste, en éste como en cualquier caso, sirve para clarificar criterios y definiciones.

La ciencia (y buena parte de la filosofía) apunta a la elaboración de un lenguaje "unívoco", es decir, un lenguaje que me deposite directamente en la cosa referida, y, por lo tanto, un lenguaje en el que "el ruido", la ambigüedad, la posibilidad del malentendido, sea reducible a cero o casi cero. Para lograr esto, el lenguaje científico/filosófico debe establecer reglas claras de significado, es decir, debe dotar a las palabras de un referente fácilmente identificable, y debe procurar eliminar de su ámbito discursivo toda palabra o construcción que genere dudas o que aliente el error hermenéutico. Se trata del ideal del lenguaje perfecto en tanto busca, entre otras cosas, liberarse de la vaguedad. En este sentido, el lenguaje científico se arma de una nomenclatura cuya característica central es la de poder circunscribir el referente de cada término de manera directa y sin error. 
Una prueba de este conato lo encontramos en la invención/utilización de palabras técnicas en donde el significante busca ser espontánea y directamente atado a un y sólo un significado, estableciéndose así una correlación uno a uno (palabra - objeto). La palabra "píloro", por tomar un ejemplo, tiene una clara definición y una asociación directa con una parte del estómago. Los contextos en los que la palabra aparece en su operatividad habitual suelen ser relacionados con la salud gastrointestinal.

La transparencia, como ideal del lenguaje científico/filosófico es algo justificado al interior del contexto disciplinar. Lo que se busca con esto es producir un medio claro de conocimiento que sea, por ello mismo, gobernable metodológicamente y comunicable intersubjetivamente. Cuando el médico disertante dice, en la Academia Nacional de Medicina, "píloro", el auditorio competente entiende una sola cosa (y el outsider probablemente nada). En esto, la ciencia no hace más que tomar una característica de la comunicación cotidiana y realzarla hasta sus posibilidades más extremas. Tanto en la ciencia como en la comunicación diaria, es necesario que emisor y receptor asocien el mismo significado a una palabra para garantizar el proceso comunicativo. Si las palabras no tuviesen un significado, la comunicación sería imposible. Pero la comunicación es un hecho. Esto parece muy elemental, pero es nodal para entender la peculiaridad de la palabra poética. Si le pidiese al comerciante cien gramos de jamón crudo, y éste me respondiese ¿̇en qué sentido "cien gramos"?, o ¿qué quiere decir con "jamón crudo"? la situación sería verdaderamente extraña, pues en el contexto de la compraventa de fiambre, mi pedido no tiene muchos pliegues interpretativos. La condición de posibilidad de la comunicación es la univocidad.

Frente a esto, "la poesía da la bienvenida a la polisemia, la metáfora, la alusión, en resumen, todo lo que probablemente concentre la mayor carga de significado en la menor cantidad de palabras posible". ${ }^{1}$ Está claro que no sólo la poesía usufructúa estas figuras retóricas, el lenguaje común, el lenguaje religioso, y otros, también las utilizan. Más aún, en la segunda parte del siglo

${ }^{1}$ De Sousa, Ronald, "The Dense and the Transparence", en Gibson, John (ed.), The Pbilosophy of Poetry, New York, Oxford University Press, 2015, p. 38. Traducción nuestra. 
$\mathrm{XX}$, muchos epistemólogos han recabado en la importancia que las metáforas tienen también en la praxis científica. ${ }^{2}$

Sin embargo, una importante diferencia entre el uso figurado del lenguaje en la poesía y en otras formas discursivas (en particular, la ciencia) está en el hecho de que para aquella la figuratividad, es esencial, y, por lo tanto, irrenunciable, imprescindible. En cambio, la utilización de figuras retóricas en el marco de la investigación científica puede ser abandonada sin pérdida epistémica. Existe un consenso importante entre científicos y epistemólogos en afirmar que, cuando la ciencia apela al lenguaje "denso" lo hace sólo con fines heurísticos o pedagógicos.

Si, en un primer acercamiento, definimos "densidad" en términos de "figuratividad", entonces debemos decir que el lenguaje poético se caracteriza por "decir más" de lo que dice. Es decir, la palabra poética libera dimensiones semánticas que la practica científica (y muchas veces la práctica ordinaria) tiende a cerrar. Este "excedente de sentido" (la expresión es de Ricoeur) instaura una pluralidad de niveles interpretativos y arrastra al lector más allá de la literalidad: "El mar en los antiguos mitos babilónicos significa más que un cuerpo de agua que puede ser visto desde la orilla. $\mathrm{Y}$ el amanecer en un poema de Wordsworth significa más que un simple fenómeno meteorológico". 3

Si esto es así, la poesía resignifica el concepto semiótico y semántico de "ambigüedad" al desplazarlo de su función entorpecedora de la comunicación hacia una idea positiva de apertura y riqueza. Para la palabra poética (y para la obra literaria en general), la ambigüedad es la clave que permite un desplazamiento de la referencia de "primer grado" (descriptiva de nuestra relación con los objetos de uso cotidiano) hacia una referencia de segundo grado, más originaria. Gracias a, y por medio de, la ambigüedad pueda la poesía "redescribir el mundo". ${ }^{4}$ Es una característica paradójica del lenguaje denso, ya

\footnotetext{
${ }^{2}$ A quienes estén interesados en esta línea, sugiero el introductorio trabajo de Palma, Héctor, Metáforas y Modelos Científicos, Buenos Aires, Libros del Zorzal, 2008. En especial, el capítulo uno.

${ }^{3}$ Ricoeur, Paul, Teoría de la Interpretación. Discurso y excedente de sentido, Buenos Aires, Siglo XXI, 2006, p. 68.

${ }^{4}$ Una vez establecida la relación entre "ambigüedad" y "figuratividad" (ambos conforman lo que venimos llamando "lenguaje denso"), Ricoeur subraya la
} 
que, como vimos, la ambigüedad es un elemento indeseable dentro de la comunicación cotidiana (pues nos dispone fuertemente al malentendido, a la incomunicación, aunque el contexto de enunciación, por lo general, la neutralice).

Claro que, para que la ambigüedad sea efectiva es necesario que esté contenida, reglamentada, limitada. Significar muchas cosas no es significar cualquier cosa. Cabe recordar que la ambigüedad es la capacidad que tienen ciertas construcciones semánticas de multivocidad, lo que no se debe asociar con falta de claridad o precisión. Para esto último el castellano reserva la palabra "vaguedad" (y, más técnicamente, "anfibología”).

Además de la figuratividad y la ambigüedad, el concepto de "lenguaje denso" tiene una tercera característica esencial (muy relacionada, desde luego, con las otras dos). Me refiero a la capacidad que tiene este lenguaje de decir en el modo de la alusión. En efecto, la palabra poética tiene un poder de condensación gracias al cual reagrupa un conjunto de imágenes que se hacen presentes sin ser referidas directamente. Sugerir es un modo de implicar no inferencial, es decir, es un modo de reunir alrededor de una palabra (o sintagma) otras palabras o sintagmas cuya fuerza sólo se aprecia mientras se mantengan en estado de coimplicación. No se trata de que de un enunciado podamos (dialécticamente, o deductivamente) extraer otros. Por el contrario, el significado de la palabra poética se caracteriza por aludir, evocar. Se trata de una forma de hacer presente sin ser explicitado ni explicitable. Invocar, provocar, evocar, son formas en las que la poesía determina y caracteriza su referente. Elegí esos términos porque comparten el sufijo "vocare" que comporta a la vez el carácter fundante de la lingüisticidad y el modo de hacer presente a través del llamado:

dependencia de este modo lingüístico de un tipo de experiencia que, por su misma densidad, lo exige. En su crítica al inmanentismo estructuralista, Ricoeur enfatiza la relación "lenguaje - experiencia (extralingüística)" incluso en el caso de la ambigüedad: "El doble sentido está al servicio, entonces, de una experiencia para decir que no encuentra en el discurso informativo su expresión. Bien se podría decir, por analogía, que es la ambigüedad de la experiencia la que apela a la ambigüedad del discurso" (Ricoeur, Paul, Herméneutique: Cours professé à l'Institute Supérieur de Philosophie de l'Université Catbolique du Louvain, Paris, Fonds Ricoeur Édition, 2013, pp. 44-45. Traducción nuestra). 
"Entonces, en un nivel, esta noción de densidad parece provenir del poder del lenguaje poético para evocar más de lo que dice". ${ }^{5}$

Una forma de aclarar este rasgo es señalando el modo indirecto en que se pone en juego. Este "carácter indirecto" conecta con las otras características de la densidad que vengo desarrollando.

Podemos entonces decir que lo que un poema afirma está relacionado con lo que sugiere, así como su significación primaria está relacionada con su significación secundaria, y donde ambas significaciones caen dentro del campo semántico. Y la literatura es ese uso del discurso en donde varias cosas son especificadas al mismo tiempo, y donde no se requiere que el lector escoja entre ellas. Es el empleo positivo y productivo de la ambigüedad. ${ }^{6}$

La tercera característica del "lenguaje denso" es la identidad "formacontenido". "En poesía, cómo se dice algo debería estar tan integralmente relacionado con lo que se dice que debería haber una sola forma posible de expresar cierto contenido". 7 Si esto es así, la verdad que vehicula el poema es inseparable del modo expresivo. "Lo que el poema dice", se dice de esa única manera. ${ }^{8}$ Lo poético de un poema no es un ornamento que busca embellecer, persuadir, motivar, lograr una determinada disposición anímica en el lector, un "envoltorio" que el poeta elija para expresar un "tema" que ya posee de antemano. Es un error suponer que el poeta tiene algo en mente y que luego busca la mejor manera de decirlo. Por el contrario, lo que el poeta ve, sólo lo ve en el medium del lenguaje poético. "El principio general de la inseparabilidad de la intuición y la expresión tiene una fuerza especial en la intuición estética. Aquí se entiende que forma y contenido, o contenido y medio, son

${ }^{5}$ Gibson, John (ed.), The Philosophy of Poetry, p. 45.

${ }^{6}$ Ricoeur, Paul, Teoría de la Interpretación, p. 60.

${ }^{7}$ Gibson, John (ed.), The Philosophy of Poetry, p. 32.

8 Probablemente, la novela no tenga esta característica. 
inseparables. El artista no intuye primero su objeto y luego encuentra el medio apropiado". 9

La unión indisoluble "forma - materia" se conjuga, en el poema, con el viejo principio hermenéutico de la relación "parte - todo", cada palabra recibe su significado en relación con la totalidad de las otras palabras, y la totalidad puede ser advertida en la densidad de cada palabra. Por lo tanto, lo que el poema revela no puede ser revelado utilizando otro entramado simbólico, no hay enunciados equivalentes que podamos utilizar como herramientas de sustitución.

De esta unión consustancial modus dicendi - desocultamiento tenemos experiencia cada vez que queremos transmitir lo que un poema dice. Es muy evidente la esterilidad del intento, y no necesariamente por falta de pericia de quien describe. Se trata, más bien, de una característica esencial del poema (y de la obra de arte en general), según la cual lo que dice se dice del modo en que el poeta lo dice. Puedo contarte que el poema "La Recoleta" trata sobre el famoso cementerio enclavado en el corazón de la Ciudad de Buenos Aires, que allí Borges intercala impresiones sensibles con intuiciones existenciales: habla de las frescas plazuelas del cementerio, de los mármoles, la belleza de los sepulcros, de los árboles y sus pájaros, y también de la finitud humana, del enigma del tiempo, de lo inverosímil de la muerte, etc. Pero, en el mismo momento que desarrollo mi descripción, siento que lo que el poema revela no es eso, que lo que describí está lejos, muy lejos, de lo que el poema dice; tan lejos que hubiese sido lo mismo no decir nada. Mejor hubiese sido convidar la lectura del poema. No hay forma de decir lo que el poema dice, salvo decirlo como el poema, esto es, decir el poema. ${ }^{10}$

\footnotetext{
${ }_{9}^{9}$ Brooks, Cleanth, The Well Wrought Urn. Studies in the structure of poetry, Londres, Dobson books, 1960, p. 183

${ }^{10}$ Esta incapacidad de sustitución se aplica al arte en general. Contar de qué trata "La Peste" da como resultado una inevitable distorsión. Lo mismo con una película, o un cuadro. Si alguien me pregunta qué representa "El Guernica" puedo referir los ominosos efectos del bombardeo a la ciudad de Guernica en abril de 1937, en el contexto de la guerra civil española. Puedo inclusive tratar de describir más: hablar de los "trozos" humanos y animales, abundar en detalles, en teorías del arte. Puedo también narrar aspectos biográficos de Picasso, vicisitudes coyunturales
} 
Si esto es así, no hay enunciación "positiva, directa, literal" de lo que un poema dice. En la poesía, quizá como en ninguna otra forma discursiva, se advierte la dimensión del problema de la traducción. Traducir, en efecto, es "decir lo mismo de otra manera". La traducción se ejerce de una lengua a otra, o de un sistema lingüístico a otro. Es lo que hacemos cuando pasamos los escritos de Hobbes del inglés al castellano (por ejemplo), o cuando explicamos un argumento con otras palabras (tal vez más familiares, compresibles, llanas). Si esto es así, entonces la condición de posibilidad de la traducción es la separación del significado y el significante, lo que, a su vez, presupone la "idealidad del sentido": la palabra inglesa " dog" tiene el mismo sentido que la palabra castellana "perro". Pero esta práctica no siempre se muestra dócil. Los grandes traductores de las obras clásicas comienzan sus textos con la misma advertencia: las palabras en su idioma original, en su circulación habitual, están sustentadas en (al tiempo que configuran) relaciones semánticas inconscientes, históricas, operativas, que forman su significado. Esa red semántica es intraducible.

Lenguaje y pensamiento se entretejen, inextricablemente, y actúa el uno sobre el otro. Las palabras tienen su historia y sus asociaciones, las cuales constituyen, para quienes las emplean, una parte muy importante de su significado, sobre todo porque sus efectos son inconscientemente sentidos, más bien que aprehendidos intelectualmente. Aun en idiomas hablados en una misma época, aparte de unas pocas palabras que designan objetos materiales, es prácticamente imposible traducir un vocablo de manera que produzca exactamente la misma impresión en un extranjero que la palabra original produce en quienes la oyen en su propia tierra. ${ }^{11}$

La poesía representa el grado extremo de esta dificultad. En ella la traducción se convierte en una verdadera lucha por la fidelidad, debido a que

contemporáneas a la obra, etc. Siempre, el final de una detallada exposición estará coronado por el sentimiento de empobrecimiento, de falsificación; siempre sentiremos que "lo mejor" (el mejor modo de comprender la obra; el único modo de comprender la obra) es contemplar el cuadro.

${ }^{11}$ Guthrie, William Keith Chambers, Los filósofos griegos, México, FCE, 2010, pp. 10-11. 
allí cada palabra (en su idioma) cumple un papel único, irremplazable, tanto por su sonoridad como por su potencial evocativo.

No hay, entonces, ninguna otra forma de decir lo que el poema (o la obra de arte en general) dice. Buscar otras figuras retóricas para expresar "el tema" del poema es generar otras imágenes que tendrán otras ramificaciones significantes. Por eso la obra de arte representa el caso paradigmático de intraducibilidad, no solo de una forma del lenguaje a otra (del lenguaje poético al lenguaje común, o al científico), sino de un idioma a otro. Se trata de una vieja enseñanza de la retórica clásica: las aliteraciones, los ritmos, las rimas, las asonancias, los énfasis, etc., son también el sentido del poema.

$\mathrm{Al}$ decir que el poema representa un límite para la traducción intercepto también la posibilidad de la "paráfrasis", y de la "explicación". En efecto, si la "paráfrasis" es la búsqueda de resignificación en otro nivel categorial, entonces es inaplicable en aquellos lugares en donde se da la identidad forma contenido. A su vez, la explicación, al buscar establecer contextos históricos, culturales, socioeconómicos, geográficos, etc. de una obra; al relacionar el contenido de la obra con la biografía del autor; al establecer esquemas, modelos, interconexiones conceptuales (que permitan armar mapas generales de un autor, o de una idea que se ramifica de diversas formas); intenta hacer "más comprensible" el sentido. ${ }^{12}$ Pero lo esencial del poema no queda siquiera rozado por este trabajo. La búsqueda de esquemas explicativos se realiza con la doble finalidad de clarificar y dominar. Si aceptamos el principio de intraducibilidad, entonces, los esquemas actúan como encubridores. Borges realiza una comparación para mostrar cómo la esquematización pauperiza. Toma como ejemplos dos versos, uno de Yeats ("bodily decrepitude is wisdom, young we loved each other and were ignorant") y otro de Meredith ("Not till the fire is dying in the grate / Look we for any kinship with the stars"), y afirma:

${ }^{12}$ Esta es una de las tesis que Ricoeur ha defendido con insistencia (cfr. Ricoeur, Paul, Del texto a la acción, Buenos Aires FCE, 2002, p. 150 y ss.). Su eslogan "explicar más para comprender mejor" invita a operar un arduo trabajo de análisis a las obras literarias con el fin de hacerlas más comprensibles. En este sentido, la "vía larga" de la hermenéutica ricoeuriana no queda reducida a los textos filosóficos, sino que tiene competencia también en la estética. Lo que estamos sosteniendo es, precisamente, lo contrario. Cuando de literatura (y poesía) se trata, la pulsión explicativa entorpece, oblitera. 
"los dos fragmentos (...) significan más o menos lo mismo. Pero pulsan cuerdas totalmente distintas. Cuando nos dicen, o cuando yo ahora les digo, que significan lo mismo, ustedes instintivamente, y con razón, entienden que eso es irrelevante, que los poemas son radicalmente distintos". ${ }^{13}$

Quiero señalar una última característica del lenguaje poético en tanto lenguaje denso. Al decir que, al menos en el campo de la poesía, el lenguaje no es un instrumento que apliquemos a algo pre-establecido, estoy señalando una unión indisoluble "forma - contenido", de ninguna manera estoy diciendo que no hay forma y contenido. El punto es polémico (y problemático).

En general el lenguaje denso responde a una necesidad de la experiencia, de los hechos y objetos que quieren venir al lenguaje. Es decir, hay experiencias cuyo volumen no puede ser expresado en lenguaje literal, conceptual, sin sentir una pérdida importante. En este sentido, el lenguaje denso responde a una exigencia del "objeto". El amor, la angustia, la culpa, la muerte, el tiempo pueden ser algunas de las cosas que requieran lenguaje denso. Ricoeur, por ejemplo, confiesa que se topó con la hermenéutica cuando decidió abordar el problema del mal. Al momento de ingresar en el problema descubrió que las diferentes culturas expresan dicho problema en términos de símbolos y metáforas: carga, mancha, desvío, etc. Esta simbólica no era un extra opcional. Fue la necesidad de aclarar el problema del mal lo que lo puso en el camino del lenguaje figurado, del desdoblamiento significativo. ${ }^{14}$

El mismo poeta nos dice que lo que escribe responde a un llamado, a una necesidad de la cosa dicha de ser dicha de esa manera. Esto puede parecer

13 Borges, Jorge Luis, Arte poética, Madrid, Espasa, 1997, p. 191.

14 "La consideración del problema del mal trajo al campo de la investigación nuevas perplejidades lingüísticas que no aparecieron antes. Estas perplejidades estaban relacionadas con el uso del lenguaje simbólico como un enfoque indirecto al problema de la culpa. ¿Por qué un enfoque indirecto? ¿Por qué el lenguaje simbólico cuando tenemos que pasar de una filosofía de la finitud a una filosofía de la culpa? Esta es la pregunta que me intrigaba. El hecho es que tenemos un lenguaje directo para decir propósito, motivos, y "yo puedo", pero hablamos del mal por medio de metáforas como desvío, vagabundeo, carga y cautiverio". (Ricoeur, P., "Del existencialismo a la filosofía del lenguaje, en AA.VV, Del existencialismo a la filosofía del lenguaje, Buenos Aires, Proyecto CINAE, 1983, p. 10). 
una contradicción en relación con la última característica del lenguaje denso que señalamos. En efecto, la identidad "forma - contenido" rechaza la idea según la cual el poeta tiene un tema y luego lo engalana con artificios retóricos. Por otro lado, decimos que "lo que el poeta quiere decir" exige un modo de ser dicho, es decir, separamos "lo dicho y el decir" (materia - forma).

Creo que podemos sortear la aporía, pero no el enigma. El lenguaje denso es, a un tiempo, continente y contenido, constituyente y constituido. Quizá debamos aplicar el método que vengo pregonando: restituir el carácter denso del lenguaje escuchando la resonancia de las palabras. El poeta crea en la medida que recibe. Dicha experiencia queda debidamente expresada en la estructura bifronte de la palabra "inventar". El enigma del lenguaje denso es “que 'inventa' en el doble sentido de la palabra: aquello que crea, lo descubre; y aquello que encuentra, lo inventa". ${ }^{15}$

\section{c) La apertura del significado: entre ontología y semiótica}

En el siglo pasado, la noción de "lenguaje denso" ha sido reforzada con dos soportes categoriales importantes. La noción heideggeriana de "significatividad" ha servido, entre otras cosas, para elaborar lo que podríamos denominar una "ontología densa", sustento referencial del lenguaje denso. Por otro lado, la semiótica ha ofrecido un análisis de la noción peirceana de "interpretante" que resignifica la naturaleza del signo y lo armoniza con la ontología densa. Pivotear entre ontología y semiótica abrirá la noción de lenguaje denso a nuevas aristas, lo que permitirá una mejor comprensión de la naturaleza y el alcance de nuestro concepto rector. No es mi intención bucear en las profundidades de dos categorías complejas y difíciles de abarcar en pocos renglones. Simplemente apelo a ellas para clarificar (y enriquecer) el concepto de "lenguaje denso" proponiendo nuevas aristas y líneas de desarrollo.

En sus escritos anteriores a Sein und Zeit, Heidegger desarrolla una trabajosa y muy penetrante crítica a la "primacía de la teoría" que ha definido y conducido a la filosofía desde sus orígenes hasta nuestros días. El epicentro de la crítica consiste en develar el modo en que la teoría desprecia, pauperiza,

${ }^{15}$ Ricoeur, Paul, La metáfora viva, Buenos Aires, Megápolis, 1977, p. 356. 
y finalmente elimina, la vivencia natural del mundo circundante. En pocas palabras, Heidegger advierte que en la actitud objetivante del filósofo (que no es exclusiva de él) opera una metamorfosis del sujeto de análisis dando como resultado la explicación de algo que no es lo que se quería explicar.

$\mathrm{El}$ modus operandi del filósofo consiste en tomar una vivencia y proceder a una separación de los elementos "subjetivos" y "objetivos", para luego declarar a estos últimos como lo "verdaderamente real". Así, por ejemplo, el fenómeno "ver una cruz" puede disparar los más variados sentimientos cuando los ponemos en relación con las subjetividades (puedo ver un objeto sagrado, una mera curiosidad histórica, un elemento de poder y sometimiento, etc.), pero, si apartamos estas "vivencias", nos quedaremos con la "cosa-en-sí", fetiche irrenunciable de la filosofía desde la Modernidad. La "cosa en sí" es el sedimento que queda luego de que se hace decantar el impacto que la cosa tiene en el sujeto; es decir, es la cosa menos la relación con el sujeto. En este caso podríamos decir que la definición objetiva de cruz es: "dos palos cruzados". Esa es su naturaleza real, el resto es subjetivismo. Pero... jnadie ve en la cruz dos palos que se cruzan! En realidad, nadie se relaciona primaria y espontáneamente de esa manera. Dos palos cruzados no es una cruz, no al menos para el creyente. Para llegar a ver "dos palos que se cruzan" es necesario atravesar un proceso de des-subjetivación, abandonar el modo en que me relaciono con la vivencia; pero al hacer esto elimino la vivencia y en su lugar pongo otra. ${ }^{16}$

Entonces, si lo que queremos es aclarar "nuestra vivencia", debemos mantener una fidelidad a "lo dado en ella" en contra de la tendencia distanciadora y extrañante propia de la actitud teorética. En un seminario dictado en 1919, Heidegger propone a su auditorio que se centre en la "vivencia de ver la cátedra". Cito in extenso:

${ }^{16}$ John Searle nos ofrece otro ejemplo: el dinero tiene una ontología social, es decir, es lo que es gracias al modo en que una comunidad se relaciona con él. Si me propusiera hacer una descripción objetiva del dinero, probablemente debería decir que es "papel pintado", pero esa definición no logra dar cuenta del comportamiento que los hombres de carne y hueso muestran frente al dinero. Describir el dinero en términos de "papel pintado" es describir algo que no es el dinero. Cfr. Searle, John, La construcción de la realidad social, Barcelona, Paidós, 1997, p. 44 y ss. 
¿Qué veo, superficies marrones que se cortan en ángulo recto? No, veo otra cosa. ¿Veo una caja, más exactamente una caja pequeña colocada encima de otra más grande? De ningún modo. Yo veo la cátedra desde la que debo hablar, ustedes ven la cátedra desde la cual se les habla, en la que yo he hablado ya. En la vivencia pura no se dan ningún nexo de fundamentación, como suele decirse. Es decir, no es que yo vea primero superficies marrones que se entrecortan y que luego se me presentan como caja, después como pupitre y más tarde como pupitre académico, como cátedra, de tal manera que yo pegara en la caja las propiedades de la cátedra como si se tratara de una etiqueta. Todo esto es una interpretación mala y tergiversada, un cambio de dirección en la pura mirada interior de la vivencia. Yo veo la cátedra de golpe, por así decirlo, no la veo aislada, yo veo el pupitre como demasiado alto para mí. Yo veo un libro en el pupitre como algo que inmediatamente me molesta (un libro, y no un numero de hojas estratificadas y salpicadas de manchas negras); yo veo la cátedra en una orientación, en una iluminación, en un trasfondo. ${ }^{17}$

Si nos propusiéramos captar la vivencia del mundo circundante tal como ella se da antes o más allá de toda teorización, el andamiaje categorial de la filosofía no es el modo adecuado.

Heidegger llama significatividad (Bedeutsamkeit) al "en-cuanto-qué" y al "cómo" del ocurrir. En este sentido, las cosas no son meros objetos que se enfrentan a un sujeto, sino que están cargadas de significado, son, diríamos, un haz de significaciones. Nadie percibe en el mundo "objetos compuestos de materia y forma"; las cosas se presentan en forma determinada, como esto o lo otro, y aglomeran en torno a sí (la expresión es algo contradictoria en este contexto) una serie indefinida de vivencias. Lo que el concepto de significatividad viene a mostrar es que la ontología no es algo que subyace a ese conglomerado.

En la mesa (en "esa mesa") se agrupan todas aquellas vivencias que la tienen como protagonista. En este sentido podemos decir que la mesa las "alude". Lo que quiere subrayar Heidegger es que la significatividad es el modo de ser de las cosas en su habitualidad y concreción media. El concepto de

\footnotetext{
${ }^{17}$ Heidegger, Martin, La idea de la filosofía y el problema de la concepción del mundo, Barcelona, Herder, 2005, pp. 85-86.
} 
"significatividad" puede, entonces, fungir como el horizonte ontológico del concepto de densidad, ya que supone el mismo poder de condensación de una multiplicidad significativa. Como afirma el propio Heidegger "un juguete estropeado y casi irreconocible es la propia infancia". ${ }^{18}$ Es decir, un objeto no se define por sus predicados esenciales, si por éstos entendemos universales y objetivos (si fuera así, un juguete sería un objeto para la diversión de los niños); por el contrario, la ontología se teje al calor de la relación que une sujeto-objeto (si se me permite una nomenclatura del todo ajena a Heidegger). En este caso, el juguete contiene toda la infancia, tiene el poder de abrir un mundo, es decir, contiene lugares, personas, acontecimientos, etc. Podríamos hablar, en el caso de Heidegger, de una "ontología densa".

El concepto de significatividad obtiene un refuerzo semiótico con el ensamble de las nociones "significado - campo - connotación" y su correlato la noción de "interpretante". En su intento por escapar a las aporías de una teoría del significado demasiado pegada a la noción ontológica del referente del realismo metafísico (levantado, desde la Modernidad, sobre el binomio fenómeno - cosa-en-sî), buena parte de la semiótica ha definido el significado en términos de "unidad cultural". Entendemos por "unidad cultural" cualquier cosa que una cultura identifique como sujeto de propiedades. Ahora bien, lo que la semiótica ha intentado mostrar es que la identificación de una unidad cultural, su delimitación frente a otras, pone en juego un proceso de semiosis virtualmente ilimitado, denso. Peirce acuña la noción de interpretante con la doble finalidad de explicar la naturaleza del signo y señalar su operatividad abierta. El razonamiento es sencillo: para decir lo que significa una palabra, tengo que acudir a otra/s palabra/s, o a un dibujo, a una definición ostensiva, en resumen, a otro signo. "Para determinar lo que es el interpretante de un signo, hay que denominarlo con otro signo, el cual, a su vez, tiene un interpretante denominable por otro signo, y así sucesivamente". ${ }^{19} \mathrm{El}$ interpretante nos muestra que la comunicación, movida de interpretante en interpretante, delimita el "referente" de una manera asintótica, es decir, lo circunscribe sin agotarlo nunca. Por lo tanto, la unidad cultural condensa una serie de asociaciones de número variable, pero nunca igual a uno. Ahora bien,

${ }^{18}$ Heidegger, Martin, Ontología. Hermenéutica de la facticidad, Madrid, Alianza, 1998, p. 91.

${ }^{19}$ Eco, Umberto, La estructura ausente, Barcelona, Lumen, 1986, p. 63. 
si la unidad cultural fuera asequible y, eventualmente, clarificable sólo por medio de un proceso de semiosis ilimitada, la idea misma de significado quedaría en un estado imprudentemente difuso. Por ello, la noción de "interpretante" requiere la noción de "campo semiótico". Un campo semiótico (o semántico) es una totalidad, de límites flexibles, al interior del cual se inserta una palabra distinguiéndose de otras. Por ejemplo, si escucho la palabra "hidra", lo más probable es que la inserte (espontánea e inconscientemente) en el campo de la botánica. Dentro de ese campo, la palabra se asocia a algunas plantas (digamos, de la misma familia), y se distancia de otras. Tenemos entonces una doble distinción: de un campo con respecto a otros (botánica historia), y dentro del campo semiótico (hidra - clavel).

Por ello, el significado de una palabra es solidario del lugar que ocupa en una estructura compuesta de otras palabras con las que mantiene relaciones de atracción y repulsión. Una unidad cultural se identifica en la medida que existe otra con valor diferencial. Es la relación entre términos de un campo lo que priva a una de lo que aporta la otra. La idea de relación diferencial nos importa en la medida que la elección de una palabra puede responder a contrastes y matices con otras del mismo campo con las que goza de cercanía, pero con las cuales no debe identificarse.

La importancia de lo que se dice depende de lo que no se dice. El enunciado realmente pronunciado contrasta y toma su forma de lo que no es, pero podría ser pronunciado sin desviación. El hecho de que "excelente", "espléndido" y similares estén disponibles y, sin embargo, no se empleen, sirve para determinar la importancia de "ésa es una buena pintura". ${ }^{20}$

Entonces, la secuencia de interpretantes que revive el proceso de semiosis al interior de un campo semiótico reposa en la capacidad que tienen las palabras de asociarse con otra/s. En este sentido, el significado de una palabra es un paquete compuesto de otras palabras asociadas, directa o indirectamente, con aquella. "la connotación es el conjunto de todas las

${ }^{20}$ Ziff, Paul, Semantic Analysis. New York, Cornell University Press, 1969, p. 147. Traducción nuestra. 
unidades culturales que una definición intensional del significante puede poner en juego, y, por lo tanto, es la suma de todas las unidades culturales que un significante puede evocar institucionalmente en la mente del destinatario". ${ }^{21}$

Esto hace juego con la idea de multivocidad. Si el significado es solidario de la connotación, las palabras significan muchas cosas. Es esta asociatividad plural lo que da basamento semiótico al concepto de lenguaje denso. La circunferencia con que cada término delimita el alcance de su polisemia es, desde luego, flexible. Hay palabras de área restringida ("píloro”), y hay palabras con más capacidad connotativa (nosotros diríamos, más "densas"). Pensemos por ejemplo el modo en que el significante "Dios" (para un conjunto de fieles) acarrea otros tales como "rey, padre, señor, pastor, roca, fortaleza, creador, siervo, redentor, perfección, amor" etc.

Es importante aclarar que las relaciones de connotación están basadas en códigos de variada amplitud y que, por lo tanto, tienen un determinado nivel de institucionalización, lo que garantiza la intersubjetividad de la cadena asociativa. La asociación "perro - fidelidad", por ejemplo, es una relación altamente codificada.

Se establece así un vaivén entre un aspecto ontológico y uno semiótico. Ambos se recubren mutuamente y evitan sus propios excesos. Del lado de la ontología, el peligro de sortear la importancia del lenguaje en la conformación del referente, $\mathrm{y}$, del lado de la semiótica, el peligro de un repliegue al interior del lenguaje sin referencia a lo extralingüístico.

Algunos autores prefieren ingresar en el fenómeno de la connotación por medio de la distinción fregeana Sinn (sentido) - Bedeutung (denotación). La "denotación" corresponde al objeto designado por la expresión, mientras que el "sentido" es el conjunto de especificaciones que nos permiten identificar el referente, y que, por lo tanto, lo presentan de una determinada manera. Se establece una distinción entre el objeto y el modo en que presentamos (o se nos presenta) el objeto. Es decir, un aspecto objetivo y uno subjetivo. Para una importante fracción de filósofos analíticos del lenguaje, el significado de una expresión no es más que el modo en que contribuye a establecer las "condiciones de verdad" de una sentencia en la cual interviene. Esto, a su vez,

${ }^{21}$ Eco, U., La estructura ausente, p. 89. 
supone que dos sentidos que tengan el mismo referente son intercambiables en cualquier contexto en los que aparecen. Si es verdad que Edipo se casó con Yocasta, y es verdad que Yocasta es la madre de Edipo, entonces es verdad que Edipo se casó con su madre. En este sentido no hay ninguna diferencia extensional entre "Yocasta" - "madre de Edipo". Esta obsesión por identificar "significado - condiciones de verdad" relega la connotación al ámbito puramente subjetivo, contingente y eliminable de una explicación del significado. ${ }^{22}$ Por lo tanto, para esta línea de pensamiento, sólo la denotación implica cognición, mientras que la connotación pertenece al costado más subjetivo del enunciado, por lo general asociado a cuestiones emotivas. Esto, a su vez, ha llevado a expulsar las obras poéticas y literarias del campo del conocimiento.

Por el contrario, la semiótica muestra que lo que llamamos "denotación" es la cristalización de una posibilidad asociativa generada por necesidades prácticas. En otras palabras, la denotación es una connotación privilegiada, en el sentido de un interpretante lógico final consagrado por el hábito comunicativo. Es decir, las diferentes situaciones en las que se ejerce el comercio comunicativo provocan un recorte de la cadena asociativa imponiendo un interpretante como representante del sentido. A esto se le llama "principio de economía del lenguaje", fundamental para el contacto dialogal.

Si esto es así, entonces la poesía, el lenguaje denso, viene a romper la estructura cristalizada de la comunicación cotidiana. Lo hace rehabilitando asociaciones relegadas por el hábito comunicativo, y creando nuevas asociaciones.

\section{d) Fijación y liberación: dejarlo implícito}

Lo que llamamos "principio de economía del lenguaje" opera en sentido contrario a lo que llamamos "lenguaje denso". Aquel, al coronar una de las ramificaciones semánticas del signo, cercena el entramado significativo. Si bien

${ }^{22}$ Cfr. Lamarque, Peter, The opacity of narrative, New York, Rowman and Littlefield, 2014, p. 4 y ss. 
lo hace por razones de pragmática comunicacional, lo cierto es que causa un empobrecimiento del capital semiótico del significante. El uso poético del lenguaje, por el contrario, busca liberar la capacidad connotativa de las palabras. La estrategia central de la rehabilitación consiste en subrayar el carácter "denso" del lenguaje.

Uno de los que mejor demostró el daño que el principio de economía del lenguaje genera en la mente del filósofo fue Nietzsche. En sus escritos de retórica señala lo que considera una decadencia fatal (en el sentido de "inevitable") a la que están sometidos los grandes conceptos que forman la cartografía de la filosofía ("sustancia", "logos", "causa", "bien", "verdad”, etc.), y que explica, por contraste, la importancia el lenguaje denso. Su tesis principal, es que todas aquellas palabras (y algunos sintagmas) son tropos retóricos (metáforas, metonimias, sinécdoques) a los que el tiempo y la repetición, les va quitando su eficacia. ${ }^{23}$

La tesis ya era antigua en la época de Nietzsche. Vico, Rousseau, Herder, Hamann, por nombrar sólo algunos, sostuvieron algo muy parecido. La idea central es que las palabras surgen por necesidades prácticas, vitales, cotidianas, y, por lo tanto, están investidas de imágenes y transposiciones. Borges, siguiendo a Chesterton, afirma que "la lengua no es como el diccionario nos sugiere, un invento de académicos y filólogos. Antes bien, ha sido desarrollada a través del tiempo, a través de mucho tiempo, por campesinos, pescadores, cazadores y caballeros. No surge de las bibliotecas, sino de los campos, del mar y de los ríos, de la noche y del alba". ${ }^{24}$ Por eso las palabras están cargadas de una gravitación física, carnal, empírica. ${ }^{25}$ Luego, por obra de la repetición y del

\footnotetext{
23 "Este es el primer punto de vista: el lenguaje es retórica, pues sólo pretende transmitir (übertragen) una doxa y no una episteme. Los artificios más importantes de la retórica son los tropos, las designaciones impropias. Pero todas las palabras son en sí, y desde el principio, tropos" (Nietzsche, Friedrich, Escritos sobre Retórica, Madrid. Trotta, 2000, p. 91).

${ }^{24}$ Borges, Arte poética, p. 187.

25 "Hubo quizá un momento en el que la palabra "luz" parecía resplandecer, y la palabra "noche" era obscura. En el caso de "noche", podemos conjeturar que en el principio significaba la noche misma: su obscuridad, sus amenazas, las estrellas radiantes. Luego, después de mucho tiempo llegamos al sentido abstracto de la palabra noche" (Borges, Arte Poética, pp. 185-186).
} 
conato abstraccionista, las palabras pierden ese lustre mundanal y se transforman en términos generales sin anclaje. Para algunos autores, la función de la poesía es devolver a las palabras su "magia" originaria, regateada, soslayada, por la incursión de la teoría. ${ }^{26} \mathrm{El}$ concepto de "lenguaje denso", al liberar al lenguaje de su anquilosamiento, se asocia también a esta capacidad que tiene la palabra poética de restaurar su áurea primigenia, atada a las necesidades y experiencias vitales, terrenales.

Por ejemplo, Nietzsche recordaba que la palabra "ser" estaba asociada directamente a la palabra "vida". La vida era la acción de respirar. Si a algo que no respiraba se le asignaba el ser, se lo hacía solo en términos analógicos (metafóricos). ${ }^{27}$ Es claro que, gracias a más de treinta siglos de insistente metafísica, la palabra "ser" se ha extendido más allá de respirar, y ha trocado su carácter metafórico: decir que la provincia de Buenos Aires es, no es hablar metafóricamente.

Otro ejemplo, muy del gusto de Nietzsche, es la gravosa sustitución del efecto por la causa (metonimia) que subyace en la sustantivación de ciertos adjetivos. Llamamos "honesta" a una acción por que, de alguna misteriosa manera, participa de la "honestidad". Llamamos bella alguna cosa porque "la belleza" está en ella. Nietzsche advierte, incluso, que buena parte de los exabruptos en los que ha caído la filosofía, de abolengo platónico, se debe al "olvido" del carácter retórico de algunas construcciones semánticas, olvido que provoca un cambio en la matriz de relación que une sujeto y predicado en los enunciados filosóficos: pasamos de una relación analógica a una de identidad.

Todos los conceptos surgen por igualación de lo desigual. Aunque una hoja jamás sea igual a otra, el concepto de hoja se forma prescindiendo

\footnotetext{
${ }^{26}$ En el texto antes citado, Borges ensaya una idea similar: "la idea de que las palabras fueron mágicas en un principio, y son devueltas a la magia por la poesía es, creo, verdadera" (Ibidem, p. 210).

27 "El concepto de ser, ¡como si éste no revelase ya en la etimología de la palabra su origen miserable y empírico! Pues esse sólo significa, en definitiva, respirar. Cuando el hombre usa estas palabras a propósito de otras cosas, no hace sino trasferir la convicción propia de que él mismo es quien respira y vive por medio de una metáfora" (Nietzsche, F., Escritos sobre Retórica, p. 90).
} 
arbitrariamente de las diferencias individuales, olvidando las características diferenciadoras entonces provoca la representación, como si en la naturaleza hubiera algo, fuera de las hojas, que fuera la "hoja", una especie de forma original que sirviera de modelo para tejer, diseñar, recortar, colorear, rizar y pintar todas las hojas. ${ }^{28}$

Es también lo que sucede cuando hablamos del "yo" como si fuera una entidad con las "mismas" características de las cosas corpóreas: por ejemplo, ubicación en el espacio (Descartes). Al decir "te quiero con toda mi alma", si no tengo presente el carácter retórico del pronombre indefinido, puedo suponer que el alma tiene partes, como la silla tiene partes. También puedo suponer que el posesivo ("mi") alude a una relación entre un poseedor (el yo) y un poseído (mi alma). Por aquí ingresan todas las perplejidades metafísicas relacionadas al problema de la identidad personal.

Nietzsche quiere que reparemos en que estas perplejidades comprometen sólo al filósofo. ${ }^{29}$ Éste se las inventa al literalizar una expresión de naturaleza retórica. Es el deseo del filósofo de hacerse con un conocimiento universal y atemporal lo que lo lleva a operar una "transposición" (Übertragung) en los enunciados comunicativos originarios y/o cotidianos. Precisamente el mecanismo de "transposición" es lo que define la estructura de los tropos retóricos (transponer lo que se da en la parte al todo, o transponer la causa con el efecto, etc.). La trampa, afirma, está en el modo en que el filósofo transpone (traduce) el significado que las palabras tienen en su circulación natural a un significado filosófico. Es lo que sucede cuando pasamos de la imagen (particular, corporal, histórica, retórica) al concepto (universal, abstracto, atemporal).

La metáfora princeps que utiliza Nietzsche para mostrar este proceso de degradación es la del "desgaste" (con sus variantes: el uso y el abuso), y su

\footnotetext{
${ }^{28}$ Ibidem.

${ }^{29}$ Lo que quiere decir es que si alguien escucha "te quiero con toda mi alma" entiende la frase, y puede reaccionar de muchas maneras. Ahora bien, si el receptor pregunta qué distingue al alma del poseedor del alma, o si se preocupa por el número de partes que componen el alma, entonces se trata de un filósofo, un verdadero aguafiestas.
} 
complemento, el “olvido". En su pequeño escrito de 1873, Nietzsche define la verdad de la siguiente manera:

¿Qué es entonces la verdad? Un ejército móvil de metáforas, metonimias, antropomorfismos, en resumidas cuentas una suma de relaciones humanas que han sido realzadas, extrapoladas, adornadas poética y retóricamente y que, después de un prolongado uso, a un pueblo le parecen fijas, canónicas, obligatorias: la verdades son ilusiones de las que se ha olvidado que lo son, metáforas que se han vuelto gastadas y sin fuerza sensible, monedas que han perdido su troquelado y no son consideradas ahora como monedas, sino como metal. ${ }^{30}$

Es lo que llamamos "proceso de lexicalización”, cuando una metáfora es acogida por una comunidad tiene a confundirse con una ampliación de la polisemia de las palabras. La polisemia comienza a angostarse alrededor de un "centro de apoyo" (lo que la palabra "significa verdaderamente") y usos más o menos desviados (figurados). El dualismo "centro - periferia" es solidario del dualismo "sustancia - accidente", y ambos trabajan en forma sinérgica para alumbrar el binomio "objetivo - subjetivo". Bajo la tutela de esta perspectiva, la noción de lenguaje denso estaba condenada a pasar a segundo plano, al quedar atada al aspecto subjetivo del lenguaje.

Ante este diagnóstico, podemos prever cuál será el tratamiento. Si, sometidas a la abstracción y repetición, las palabras angostan su capacidad asociativa, entonces, debemos buscar un modo de hacerlas resonar nuevamente. Tenemos que buscar la manera de revivir el carácter rizomático (denso) de su significado. Nietzsche encuentra en la genealogía etimologizante una vía para intentar esta resurrección, pero advierte, rápidamente, que dos obstáculos se agrupan en este punto. Uno es la necesidad de participar de un "horizonte de sentido" (lo que llamamos más arriba "campo semiótico o semántico") para poder apreciar la resonancia de ciertas grandes palabras. Pensemos, por ejemplo, en la palabra griega logos. Para los interlocutores de Heráclito esta palabra se insertaba en varios campos semánticos y, dentro de

${ }^{30}$ Nietzsche, Friedrich, El libro del filósofo, Madrid, Taurus, 2000, p. 91. 
cada campo, se veía atraída y repelida por varios significantes (podía ser palabra, causa, explicación, fundamento, principio, texto, ley, espíritu, etc.). Recuerdo que, al estudiar la filosofía presocrática, el profesor advertía: "en griego logos tiene algo más de 53 traducciones". Para mantener el capital semántico de la palabra, hay que ser un hablante competente; en este caso, hay que participar del mundo en el cual la palabra circula bajo esa circunstancia. No alcanza con registrar la lista de significados posibles de la palabra, hay que lograr ver, en cada contexto, cuál es su sentido, y el modo en que ese sentido arrastra una serie de imágenes, experiencias, tradiciones, etc. Se trata de una condición existencial/histórica de posibilidad.

El otro obstáculo, muy incómodo para el teórico, se relaciona con la segunda característica del concepto de "densidad" que desarrollamos en el apartado (b), según la cual, para preservar (o restaurar) la resonancia de las palabras es necesario decirla de modo tal que su riqueza sea sugerida, evocada, no explicitada. Se trata de una paradoja: para que la palabra diga más de lo que dice, tenemos que asegurarnos de conservar en estado de "sugerencia" el caudal semántico. Como ya apuntamos (cuando hablamos de la traducción, la paráfrasis y la explicación), la riqueza alusiva de una palabra vive de su mismo estado de alusividad, de tal manera que "hacerlo explícito" significa una pérdida. En este sentido, la palabra poética condensa en forma de latencia toda una red de connotaciones que pende de ella.

Esto sucede porque la explicación del significado supone cortar el rizoma en alguno de sus nudos. Al hacer esto, privilegiamos (tal vez sea mejor decir "destacamos") una posibilidad asociativa por sobre las otras. Esto hace que las que han perdido su conexión con el nudo visibilizado comiencen a extenuarse, hasta finalmente desaparecer. En otras palabras, al explicitar consagro una posibilidad en detrimento de otras. A diferencia de lo que sucede en la práctica psicoanalítica, en el poema hay que mantener las asociaciones en estado latente, pues hacerlas manifiestas supone ipso facto el fin del poema. ${ }^{31}$

\footnotetext{
31 En su camino de regreso del inframundo, Orfeo siente la presencia de Eurídice caminando a sus espaldas. Sabe que la condición para encontrarse finalmente con su amada en la tierra de los mortales es que ella se mantenga así, sentida más que percibida por sus ojos. El fin de la historia es también mitológico, Orfeo no pudo resistir la agitación que le provoca esa presencia sugerida, insinuada, y gira para mirar de frente a
} 
Estos obstáculos no son impedimentos. La palabra poética permite sortearlos. Sería una especie de talismán que nos haría participar de diversos "mundos" por medio del incremento de la plusvalía semántica de las palabras. Tendríamos en el poeta, entonces, el mejor terapeuta.

En efecto, una de las características que definen a la palabra poética es su capacidad de revelar la significatividad de la experiencia, en el sentido de develar el modo en que el mundo nos es dado antes del proceso de objetivación (¿inevitable?) promovido, no sólo por el pensamiento metodológico/científico, sino, incluso antes, por la finalidad pragmática de la comunicación. El arte en general, y la poesía en particular, muestran nuestra pertenencia al ser, revelan el tipo de relación que nos liga al mundo de una manera existencial más que conceptual. Ese estrato de la experiencia, anterior a la enunciación apofántica, que Husserl llamaba "mundo de la vida" y Heidegger "significatividad", es lo que el lenguaje denso rescata, recreando aspectos del mundo que, aunque velados por los intereses pragmáticos, mantienen poder vinculante. ${ }^{32}$

\section{e) Conclusión}

La poesía ha sabido usufructuar el reposicionamiento de la retórica ocurrido en el siglo XX. De la mano del giro lingüístico, el lenguaje denso se ha ido corriendo del ingrato lugar en que había sido colocado durante muchos siglos. Ya no juega un papel meramente ornamental. Engalanar un discurso es una posibilidad del lenguaje denso, quizá su variante menos interesante. Lo que

su amada. Esa inmediatez, esa evidencia significó la muerte de Eurídice. Algo similar sucede con la densidad de las palabras, sólo se hace presente si no se percibe directamente. Cuando el intelecto quiere dominarla, la presencia desaparece. Hay que decir de la palabra poética lo que Borges afirma de la experiencia estética en general: se trata de la "inminencia de una revelación que no se produce" (Borges, Jorge Luis, Obras Completas, tomo II: "La muralla y los libros", Buenos Aires, Emecé editores, 1996, p. 13).

32 Uno de los atractivos de los artificios retóricos es que comprometen al oyente (y, en menor medida, al lector) de una manera total. Es decir, ponen en funcionamiento no sólo su capacidad racional, sino aspectos desiderativos y afectivos. 
muchos autores contemporáneos han advertido es algo que los grandes poetas y oradores de la Antigüedad sabían muy bien: la palabra tiene un poder constituyente y no sólo instrumental. El poeta tiene un papel destacado en la cultura (paideia) porque, por medio de sus palabras, logra suscitar una experiencia que se considera fundamental: la experiencia de pertenecer a un mundo común, a una historia común, a una tradición; porque el lenguaje postula una memoria compartida.

Tal vez esa experiencia está ineludiblemente atada a un modo ingenuo de estar con las cosas. Quizá el poeta represente la grieta por la que se filtra, en nuestro universo administrado y atravesado por la idea de "objetividad y dominio", el re-encantamiento del mundo.

Sea como fuere, lo cierto es que el concepto de lenguaje denso, que es otro modo de llamar al lenguaje figurado, metafórico, poético, es el tuétano de un proceso de apertura de una concepción del lenguaje, que ha ido cerrándolo en torno a un ideal de univocidad, distanciamiento e idealidad, provocando un solipsismo lingüístico muy gravoso. El lenguaje denso hace explotar al lenguaje.

El punto más destacable de esta reapertura está en lo que llamé alcance ontológico. Lo que he querido mostrar con el análisis anterior es que la densidad del lenguaje es una característica estructural, esencial, y que ese modo de ser redunda también en la posibilidad de describir el mobiliario del mundo. Por eso creí conveniente acompañar el concepto de lenguaje denso con el de "significatividad" y el de "interpretante", porque creo que estos dos conceptos restituyen la unión lenguaje - mundo al interior del juego poético.

Queda una última cuestión litigiosa. Restaurada la capacidad ontológica y epistémica del lenguaje denso, quedaría resolver la tensión entre una mirada horizontal (verdaderamente plural) y una vertical (jerárquica). En efecto, podemos reconocer que la verdad se expresa de muchas maneras, y que la poética es una de sus formas (la científica es otra). En este caso tendríamos un pluralismo (de mínima un dualismo) horizontal en el sentido de dos juegos de lenguaje heterogéneos, irreductibles e inconmensurables. Esta es la postura más irénica.

Del otro lado, tenemos una mirada que privilegia el lenguaje denso por sobre todo otro lenguaje, incluido el científico. Esta línea post-romántica ha gozado de un representante de privilegio durante el siglo pasado. El llamado 
"segundo Heidegger" se caracteriza por una concepción metafísica de la poesía, en el sentido que la palabra poética funda el ser y lo cuida en esa fundación. Es claro que, en la jerarquía ontológico-epistémica, el lenguaje denso ocupa el primer lugar, muy por encima del degradante uso científico.

Creo que la polémica entre "horizontalistas" y "verticalistas" está abierta y es uno de los debates más acuciantes de la agenda filosófica. Pero la contienda sólo puede desplegarse dentro del perímetro de un campo previamente abierto por la vindicación del lenguaje denso.

Recibido: 08/2018; aceptado: 11/2018. 